DOI: https://doi.org/10.32839/2304-5809/2021-6-94-5

удК 378

Хоменко О.Ю.

Національна академія внутрішніх справ

\title{
РОЛЬ SOFT SKILLS У ПІДГОТОВЦІ МАЙБУТНІХ ПРАВООХОРОНЦІВ
}

\begin{abstract}
Анотація. У статті розглянуто гнучкі навички, їх роль в розвитку здобувачів вищої освіти, зокрема майбутніх правоохоронців. Визначено поняття гнучких навичок, їх види, шляхи їх розвитку. Підкреслена важливість гнучких навичок для здобувачів освіти, особливо майбутніх правоохоронців, оскільки володіння лише професійними або академічними навичками є недостатнім для досягнення кар'єрного успіху. Акцентовано увагу на тому, що науково-педагогічні працівники мають переглянути підходи до планування занять, щоб органічно розвивати як тверді, так і гнучкі навички одночасно, а також вдосконалювати навчальні програми. Приділена увага ролі гнучких навичок в роботі правоохоронців, зокрема ведення допитів, опитувань та інша робота з населенням. Виділені способи розвитку гнучких навичок у майбутніх правоохоронців.
\end{abstract}

Ключові слова: гнучкі навички, комунікативні та соціальні навички, вища освіта, роль гнучких навичок, шляхи розвитку гнучких навичок.

Khomenko Olena

National Academy of Internal Affairs

\section{THE ROLE OF SOFT SKILLS IN TRAINING OF FUTURE LAW ENFORCEMENT OFFICERS}

Summary. The article considers soft skills, their role in the development of students, in particular future law enforcement officers. It is important for a modern specialist in any field to have both hard and soft skills, and soft ones are much more important. The history of the concept of soft skills is revealed, information about the latest research on the topic is briefly given, the classification of soft skills, ways of their development are given. Thus, in particular, the article discusses such skills as: communication, social, high-level thinking skills, self-control and positive self-esteem. They are interconnected, it is impossible to develop one skill and not develop all the others. The importance of soft skills for students as future young professionals in the labor market is emphasized, where they will be expected to have not only professional skills, but also communicative and organizational skills. This is especially true for future law enforcement officers, as having only professional or academic skills is not enough to achieve career success. Emphasis is placed on the fact that research and teaching staff should review approaches to lesson planning in order to organically develop both hard and soft skills at the same time, as well as to improve curricula. Attention is paid to the role of soft skills in the work of law enforcement, in particular, conducting interrogations of suspects, interviewing witnesses and other work with the population, paper work. The ways of development of soft skills of future law enforcement officers are allocated. In particular, it is emphasized that students can both take advantage of the opportunities of their own higher education institution, or master soft skills on their own using online and offline courses, books, webinars etc. In general, the topic of soft skills is very relevant both for modern higher education and in general. Researchers of this topic are actively working on scientific works, and popular science books on the topic are constantly published.

Keywords: soft skills, communicative and social skills, higher education, the role of soft skills, ways of development of soft skills.

$\prod^{\circ}$ остановка проблеми. Ситуація на сучасному ринку праці склалася таким чином, що випускнику вже не достатньо бути кваліфрікованим в своїй профресії, постійно підвищувати кваліфікацію і слідкувати за останнім словом у своїй сдрері. Від нього чекають високих комунікативних здібностей, вміння презентувати себе, проводити переговори і домовлятись, мати високі писемні навички, проводити презентащії і виступати, знати хоча б одну іноземну мову, розвивати емоційний інтелект і володіти вмінням світської бесіди (small talk). I цей список далеко не повний. Сьогодення змістило акцент 3 профресійних компетенцій на компетенції у спілкуванні.

Основа ринку праці - вільна конкуренція. Конкуренція між роботодавцями за найкращого працівника i конкуренція між робітниками за найкращі умови і оплату праці. На жаль, найбільшою є конкуренція серед молодих спеціалістів без досвіду роботи. Роботодавці чекають все більшо- го від своїх підлеглих, що змушуе молодих людей засвоювати гнучкі навички самостійно і в короткі строки. Особливо це актуально майбутнім правоохоронцям, які працюватимуть 3 людьми і користуватимуться гнучкими навичками щодня.

Аналіз останніх досліджень і публікацій. Період 1959-1972 рр. пов'язаний з редрормою системи підготовки особового складу армії США, а також дослідженням компетенщій під керівництвом Д.К. МакКлелланда. В 1968 р. США офріційно представили доктрину під назвою «Системна інженерія навчання», де було наступне визначення: “навички, пов'язані з роботою, пов'язані з діями, що впливають, перш за все, на людей та паперову роботу, наприклад, перевірка військ, нагляд за персоналом офрicy, проведення досліджень, підготовка звітів про технічне обслуговування, підготовка звітів про ефрективність, проектування мостових структур» [7]. В 1972 рощі була представлена доповідь присвячена з'ясуванню поняття «гнучких навичок». 
Так, було сфрормульовано наступне визначення: «Соціальні навички - це важливі для роботи навички, які не стосуються роботи з машинами і застосування яких на роботі є досить узагальненим» [7]. Сьогодні багато галузей віддають перевагу високому рівню гнучких навичок у своїх співробітників, а почалося все 3 тренувальних матеріалів для американської армії.

Так як розвиток м'яких навичок сьогодні $є$ надзвичайно важливим, ця тема піднімаеться в багатьох наукових і науково-популярних публікаціях. Серед зарубіжних авторів можна згадати Пола Дж. Уітмора, Пеггі Клаус, Марсель М. Робле, Джон П. Фрай, Хекман і Каутц, К.Х. Сільбер та інші досліджували суть, структуру і компоненти цих навичок. Вони вивчали можливі стратегії для розвитку м'яких навичок, аналізували ефрект цих навичок на загальну задоволеність життям людини і сощіального прогресу, що включає такі різноманітні аспекти життя як освіта, успіх на ринку праці, здоров'я, сімейне життя та інші. Хоч для вітчизняних дослідників ця тема $є$ дещо новою, все ж іiі активно досліджують зараз. Серед вітчизняних дослідників можна назвати Айзікову Л.В., Альохіну О., Делію О., Длугунович Н.А., Єжижанську Т.С., Мідляр А.К., Осадчу М.П., Шкуть О., Грішнову О.А., Семикіна М.В. та інших. Не зважаючи на актуальні напрацювання з даної теми, вона потребує подальших досліджень.

Метою даної статті $є$ аналіз поняття гнучких навичок, їх видів, стратегій розвитку і ролі в контексті підготовки майбутніх працівників правоохоронних органів.

Виклад основного матеріалу дослідження. Традиційно прийнято розрізняти два типи навичок, які необхідні сучасному спеціалісту:

- hard skills («тверді» навички) - профресійні навички, які можна продемонструвати. Наприклад, знання іноземної мови, вміння керувати автомобілем, знання мови програмування тощо.

- soft skills («м'які» або "гнучкі» навички) навички, які складно продемонструвати наочно, відстежити і перевірити, наприклад комунікативні навички або управлінські.

Сучасному спеціалісту необхідні як перша група навичок, так і друга. Перша група - це профресійні знання і навички, які необхідні спеціалісту на роботі. Друга група - соціально-психологічні навички, які потрібні людині в більшості життевих ситуацій (комунікативні, лідерські, публічні, ораторські, командні та інші). I якщо раніше тверді навички були значно важливішими для роботодавця, то зараз ситуація дещо змінилась. Керівник ймовірніше прийматиме і буде просувати працівника з високим рівнем гнучких навичок.

Що ж таке гнучкі навички? До гнучких навичок ми відносимо широкий спектр навичок, компетенцій, особистих рис які дозволяють людям ефективно організовувати своє середовище i час, добре працювати 3 іншими, презентувати себе як ефективного спеціаліста і досягати поставлених цілей, підкреслюючи свої тверді навички. Гнучкими навичками ми називаємо комбінацію комунікативних навичок, рис характеру, соціального та емоційного інтелекту. Словник Collins English Dictionary визначає термін «soft skills» як бажані якості для деяких форм роботи які не залежать від набутих знань: вони включають здоровий глузд, здатність працювати з людьми і позитивне, гнучке ставлення [9] Ці навички важко відслідкувати, визначити, виміряти і порівняти, проте на сьогоднішній день вже існують тести і методики проведення співбесід, які допомагають оцінити рівень розвитку гнучких навичок [1].

Так, гнучкі навички складно дослідити, проте, більшість дослідників ціеї теми згодні, що ключовими гнучкими навичками можна назвати наступні:

- профресіоналізм;

- надійність;

- вміння справлятися 3 невизначеністю;

- стресостійкість;

- вміння планувати і мислити стратегічно;

- здатність ефективно співпрацювати з іншими, як в команді так і через нетворкінг;

- високі навички писемного і усного спілкування;

- навички роботи з інформаційними технологіями;

- креативність і впевненість;

- високі навички тайм-менеджменту;

- готовність вчитися і брати на себе відповідальність [4].

Дослідники Ліппман Л.Х., Мур К.А. та інші виділяють такі важливі типи гнучких навичок: соціальні навички, комунікативні навички, навички мислення високого рівня, навички самоконтролю і позитивну самооцінку [6, с. 56].

Соціальні навички допомагають людям ладнати один з одним. Вони включають в себе повагу до інших, правильну поведінку згідно ситуації, розв'язання конорліктів. Ці навички потрібні не лише майбутнім правоохоронцям, які щодня стикаються з різними людьми в різних ситуаціях, часто конфрліктних. Ці навички $\epsilon$ універсально важливими для працівника будь-якої сфрери.

Комунікативні навички включають в себе специфрічні типи комунікації, які необхідні на роботі, наприклад усне, письмове, невербальне спілкування, навички слухання. Сильні комунікативні навички завжди потребують розвинутих соціальних навичок, гнучкі навички не існують поодинці, а завжди взаємодіють. Правоохоронець розвиває в собі як письмові профресійні навички (складання протоколу та іншої документації з місця злочину), так і інші комунікативні навички. Наприклад, при веденні допиту знадобляться навички усного спілкування, навички слухання і навички невербального спілкування. Також не завадять базові знання психології і етики, особливо під час спілкування зі свідками або родичами потерпілих.

Навичками мислення високого рівня називають вміння вирішувати проблеми, критичне мислення і прийняття рішень. Роботодавець очікуе від підлеглого вміння помітити і виділити проблему, зібрати інформацію 3 різних джерел щоб зважити свій вибір і прийти до раціонального висновку. Всі ці навички знадобляться майбутньому слідчому при веденні розслідування.

Самоконтроль - це вміння людини відмовитись від винагороди на деякий час, контролювати свої імпульси, спрямовувати свою увагу 
правильно, контролювати емоціі і поведінку. Самоконтроль є фоундаментальним для багатьох, він допомагає ефективно приймати рішення, вирішувати конфлікти, зрозуміло і чітко комунікувати. Працівник правоохоронних органів має розвивати цю навичку на максимальному рівні, адже він має весь час бути напоготові для будьякого розвитку подій, а під час спілкування 3 населенням важливо пам'ятати про свою поведінку і емоції. Очевидно, що попередні навички також взаємодіють і з щією.

Позитивна самооцінка включає впевненість в собі, самоедективність, самосвідомість, переконання, самоповагу, здоров'я, гордість. Позитивна самооцінка є корисною в будь-якій сырері і напрямі роботи.

Роботодавці також високо цінують сумлінну працю, надійність, відповідальність і самомотивацію. Ці та інші навички найкраще розвиваються під час навчання, особливо під час групової роботи.

Випускники, які володіють цими гнучкими навичками, без проблем знаходять вакансії i проходять співбесіди, а тому і частіше отримують пропозиції роботи. Вони, скоріше за все, працюватимуть продуктивно і просуватимуться кар'ерними сходами швидше за тих, хто гнучкими навичками не володіє [6].

Важливість цих навичок для майбутньої роботи в будь-якій сфрері важко переоцінити. Яким же чином здобувачі можуть розвинути гнучкі навички? По-перше, здобувач може скористатися тим, що пропонуе його вищий навчальний заклад. В багатьох вишах України здобувачам надана можливість працювати над своїми гнучкими навичками. Так, в Національній академії внутрішніх справ здобувач за бажанням може записатись на факультатив з риторики або етики, відвідувати розмовні клуби 3 англійської мови, де може не лише відпрацювати актуальну професійну лексику, а й обговорити з товаришами переглянуті фрільми, прочитані книги або останні новини. Також для здобувачів доступні курси 3 турецької мови, де вони мають змогу оволодіти новою для себе іноземною мовою. Протягом року проводяться лекції, що розкривають теми емоційного інтелекту, вирішення конфрліктів, взаємодії в соціумі, які теж корисно відвідати.

По-друге, здобувач може займатися розвитком гнучких навичок самостійно. В інтернеті $€$ безліч як платних, так і безкоштовних курсів, відео і аудіо лекцій 3 теми. Окрім цього, написано вже багато науково-популярної літератури про гнучкі навички, з якої здобувач може взяти багато цінної інформації написаної доступною мовою і з прикладами. Потрібно одразу налаштовуватись, що робота над гнучкими навичками довга і важка. Змінювати свої звички завжди важко, проте майже відразу здобувач побачить всі переваги володіння гнучкими навичками.

Найприемнішим способом розвитку гнучких навичок є часта соціалізація 3 друзями, одногрупниками і іншими членами соціуму. Це може звучати не дуже серйозно, проте свідоме спілкування, тобто 3 якоюсь метою, дуже добре розвиває деякі навички. Цим шляхом можна розвинути не лише навички світської бесіди (small talk), а й безліч інших комунікативних навичок. Так, наприклад під час коротких світських розмов i недормального обговорення 3 іншими різних питань ми розвиваємо в першу чергу свої мовленнєві навички в загальному, навички слухання, навички дискутування, етикет, самооцінку або мову тіла.

Українські заклади вищої освіти мають інтегрувати в методику викладання орієнтацію на розвиток здобувача як конкурентоспроможного випускника. Такі зміни означають розвиток гнучких навичок паралельно 3 розвитком твердих. Іншими словами, здобувачі, що приходять на лекційне або практичне заняття 3 метою розвитку твердих навичок, неминуче практикуються і в багатьох гнучких навичках.

Перше, що мають зробити науково-педагогічні працівники, це донести важливість розвитку гнучких навичок до здобувачів, їх користь у майбутньому. Здобувачі будуть більш зацікавлені в розвитку навичок, розширенні свого світогляду, відвідуванні відповідних курсів і фракультатив, читанні тематичних книжок. Формальним підходом буде внесення відповідних навчальних предметів до робочих програм і тематичних планів. Здобувачам молодших курсів можна задавати робити самостійні дослідження і презентувати результати групі. Заняття 3 навичок тайм-менеджменту, вирішення конфрліктів, культурних питань, або 3 самоактуалізації на практиці позитивно сприймаються старшими курсами.

Однак дуже часто робочі програми переповнені предметами для розвитку твердих навичок і додавати щось фракультативно вже не вистачає годин. Більш того, деякі науково-педагогічні працівники можуть і самі не розуміти важливості гнучких навичок, а тому не підтримувати запровадження додаткових курсів i фракультативів. Найкращим способом все ж внести м'які навички до розкладу кожного здобувача - це їх розвиток паралельно 3 твердими навичками. Таким чином, жодних змін до робочих програм вносити не потрібно, зміни відбудуться лише у підготовці і плануванні викладачами занять.

Висновки. Останнім часом гнучкі навички стали найнеобхіднішими для кожного спеціаліста. Так, сучасний роботодавець скоріше віддасть перевагу спеціалісту 3 розвинутими гнучкими навичками, ніж тому, хто володіє лише твердими. Спеціалісту будь-якої сфери важливо не лише показувати свої профресійні уміння і навички на високому рівні, а й вміти працювати і спілкуватись з людьми, організувати себе і свій час, мати широкий кругозір і т.д.

Майбутнім правоохоронцям, як і будь-яким іншим спеціалістам, гнучкі навички необхідні. Вони знадобляться не лише під час пошуку роботи, а й під час виконання своїх обов'язків. Робота з населенням, опитування свідків, допит підозрюваних, паперова робота, щодня правоохоронець стикається 3 необхідністю бути не лише досвідченим спеціалістом, а й людиною з розвинутими гнучкими навичками. I починати розвивати їх важливо вже у закладі вищої освіти, де здобувачу надаються можливості для розвитку і особистісного росту. 


\section{Список літератури:}

1. Пономарева О.Я. Сформированность гибких навыков (soft skills) как условие адаптации современного поколения к рынку труда / Актуальные проблемы социального профессионально-экономического вхождения молодежи в региональную общественно-производственную среду: материалы 2-й Международной научнопрактической конференции / отв. за вып. Л.П. Пачикова, Т.В. Филипповская; Рос. гос. проф.-пед. ун-т. Екатеринбург, 2018. С. 29-33.

2. Boyatzis R. The competent manager: a model for effective performance. New York : Wiley, 1982. 308 p.

3. Goleman D., Boyatsis R., McKee E. Emotional leadership: the art of managing people based on emotional intelligence. Moscow : Alpina Business Books, 2008. 301 p.

4. McLarty, R. Using Graduate Skills in Small and Medium Sized Enterprises. Ipswich : University College Suffolk Press, 1998.

5. McClelland, D. C. Testing for competence rather than for intelligence / D.C. McClelland. Text: print // American Psychologist. 1973. No 28. pp. 1-14.

6. Lippman L.H., Ryberg R., Carney R., Moore K.A. Workforce connections: key "soft skills» that foster youth workforce success: toward a consensus across fields. Washington, DC : Child Trends, 2017. $56 \mathrm{p}$.

7. Silber K.H., Foshay W.R. Handbook of Improving Performance in the Workplace, Instructional Design and Training Delivery. John Wiley \& Sons, 2009.

8. The report of the British Association of recruiters of graduates of higher education institutions, 2007 / AGR. URL: http://www.agr.org.uk/surveys

9. Workforce connections: Key soft skills that foster youth work-force success / L. H. Lippman, R. Ryberg, R. Carney, K. A. Moore. Text: electronic // Child Trends. 2015. URL: http://www.childtrends.org/wp-content/ uploads/2015/06/2015-24WFCSoftSkills.pdf

\section{References:}

1. Ponomareva O.Ya. (2018) Sformirovannost' gibkih navykov (soft skills) kak uslovie adaptacii sovremennogo pokoleniya $\mathrm{k}$ rynku truda [Formation of soft skills as a condition for the adaptation of the modern generation to the labor market]. Proceedings of the Aktual'nye problemy social'nogo professional'no-ekonomicheskogo vhozhdeniya molodezhi $v$ regional'nuyu obshchestvenno-proizvodstvennuyu sredu (Russia, Ekaterinburg, 2018) (eds. L.P. Pachikova, T.V. Filippovskaya), Ekaterinburg, pp. 29-33.

2. Boyatzis R. (1982) The competent manager: a model for effective performance. New York: Wiley, 308 p.

3. Goleman D., Boyatsis R., McKee E. (2008) Emotional leadership: the art of managing people based on emotional intelligence. Moscow: Alpina Business Books, 301 p.

4. McLarty, R. (1998) Using Graduate Skills in Small and Medium Sized Enterprises. Ipswich: University College Suffolk Press.

5. McClelland, D.C. (1973) Testing for competence rather than for intelligence. American Psychologist, no. 28, pp. 1-14.

6. Lippman L.H., Ryberg R., Carney R., Moore K.A. (2017) Workforce connections: key «soft skills» that foster youth workforce success: toward a consensus across fields. Washington, DC: Child Trends, $56 \mathrm{p}$.

7. Silber K.H., Foshay W.R. (2009) Handbook of Improving Performance in the Workplace, Instructional Design and Training Delivery. John Wiley \& Sons.

8. The report of the British Association of recruiters of graduates of higher education institutions, 2007 / AGR. URL: http://www.agr.org.uk/surveys

9. Workforce connections: Key soft skills that foster youth work-force success (2015) / L.H. Lippman, R. Ryberg, R. Carney, K.A. Moore. Text: electronic // Child Trends. URL: http://www.childtrends.org/wp-content/ uploads/2015/06/2015-24WFCSoftSkills.pdf 